\title{
葉緑体の光収縮現象
}

\section{伊藤 袖夫}

高等植物の光合成諸反応は, その緑葉の細胞中にあ る葉緑体を中心にして行なわれ, 葉緑体の諸性質の解 明が光合成機構の研究の中心主題になっている. 從来 知られていた葉緑体の行なら光合成諸反応を分類すれ ば, 次の 3 つの体系にまとめられよう.すなわち, 光 照射に伴う電子伝達反応 (Hill 反応), これに伴ら光 リン酸化反応, 拉よび, これら 2 つに関連する炭水化 物や蛋白質などの植物体構成物質の合成反応である.

これらからも察せられるよらに，葉緑体が明暗いずれ の条件下にあるかは, 葉緑体の生理的状態に決定的な 差異を与える. 葉緑体の生理的活性とその構造との関 係の解明は光合成機作の解明といら大目的からして興 味ある研究分野であるが, 従来, 葉緑体の構造の研究 は光の実験条件を無視して行なわれてきた．筆者らは， 光の明暗の条件を規定して葉緑体の構造を研究した結 果, 葉緑体が光により可逆的に収縮し偏平化する事実, すなわち葉緑体の光収縮現象を見いだした. これによ り，葉緑体の示す光依存性の反応体系が質的に 1 つ増 加したことになり, 光合成研究の分野はよりいっそう の広がりを有するようになってきた.この現象が見い だされたのは比較的最近のこと (1963 年)なので， あ まり多くのことを述べることはできないが，ここでは 光収縮現象, 拉よび，これに関連すると思われる諸現 象について要約してみたい.

葉緑体の光収 縮 現 象 は, 体積分布, 懸濁液の濁度 (rectilinear attenuance，または見かけの吸光度), 90 度方向の光散乱強度, 粘度, 牤よび電子顕微鏡観察な どの種々の物理化学的手法で認知できる. coulter counter による体積分布の測定結果によれば, ホウレ ソソウの遊離葉緑体は 30 分間の光照射により暗中の 体積の約 $50 \%$ に可逆的に収縮する. また, 光収縮に
伴って, 䜿濁液の濁度执よび 90 度方向の光散乱強度 が上昇することが知られている. これら葉緑体の光散 乱性の増加は葉緑体の偏平化を意味すると考えられる が，このことは電子顕微鏡観察から支持されている. 緑葉中にあるがままの葉緑体もまた, 遊離葉緑体の場 合と同様に光収縮現象を示す (写真参照). 喑中に拉 ける丸味を帯びた葉緑体は, 光照射により細胞壁に垂 直な方向に収縮偏平化する. この写真では判然としな いが, 遊離葉緑体を明暗条件下でオスミウム酸で固定 した場合の電顕像を検討した結果, 光収縮に伴って葉 緑体中のラメラの相互間隔が縮小してくることがわか った. な挔，光収縮の作用スペクトルを測定した結果， 光収縮は, 主としてクロロフィル $a$, 拈よび 720〜740 $\mathrm{m} \mu$ に光吸収帯を有する, ある種の未知色素によって 吸収された光のエネルギーにより駆動されることがわ かった。

新たに見いだされた光収縮現象と, 従来から知られ ている葉緑体の光化学的諸性質との関連が興味を引く が, 多くの研究者による実験結果を総合すると, 光収 縮現象は葉緑体内に生ずる光リン酸化反応と密接に関 連していると結論される.たとえば, 光収縮の活性は リン酸イオンが存在しなければ発現せず, 光リン酸化 のアンカップラーにより強く阻害される. また, ATP が葉緑体を収縮させることも知られている.

光により葉緑体の体積が変化するということは, 葉 緑体膜を通しての物質交換が光により影響を受けるこ とを示している．光収縮の活性が浸透圧の影響を受け るといら知見は, このへんの事情を物語るものであろ う. 光収縮現象に関連して, $\mathrm{Na}^{+}, \mathrm{K}^{+}, \mathrm{Mg}^{++}, \mathrm{Ca}^{++}$ 特よびリン酸イオンの葉緑体膜に対する透過性が光に より変化するという知見もある (Packer ら, Dilley 
ら). これらイオンの透過性 は, いわゆる能動輸送の機構 により制御されていると思わ れるが，今後の検討が望まれ る. 光収縮叔よび物質出入り に関連して與味深いのは, 光 照射すると葉緑体懸濁液の $\mathrm{pH}$ が上界することであるら (Jagendorf ら). 光による光 散乱強度の上昇量は, 液にア ルカリを加えると減少するこ とも知られている (向畑). 以前から, 葉緑体扣よびミト コンドリアなどのエネルギー 産出粒子の膜に $\mathrm{H}^{+}$の濃度勾 配をかけると，リン酸化反応 が生ずる可能性が指摘されて いたが，事実，Jagendorf ら により,このことが葉緑体に ついて成立することが見いだ された.このことと関連して， さらに, 外液の $\mathrm{pH}$ を変化さ せると葉緑体の構造が変化す ることが最近知られた(Packer ら). これらの事実から判 断すると, 光リン酸化に共役 する光収縮現象と, $\mathrm{H}^{+}$濃度 勾配による瞕中でのリン酸化 と同様な条件下での葉緑体の 構造変化とは，相互に密接な 関係を有すると結諭されよう。

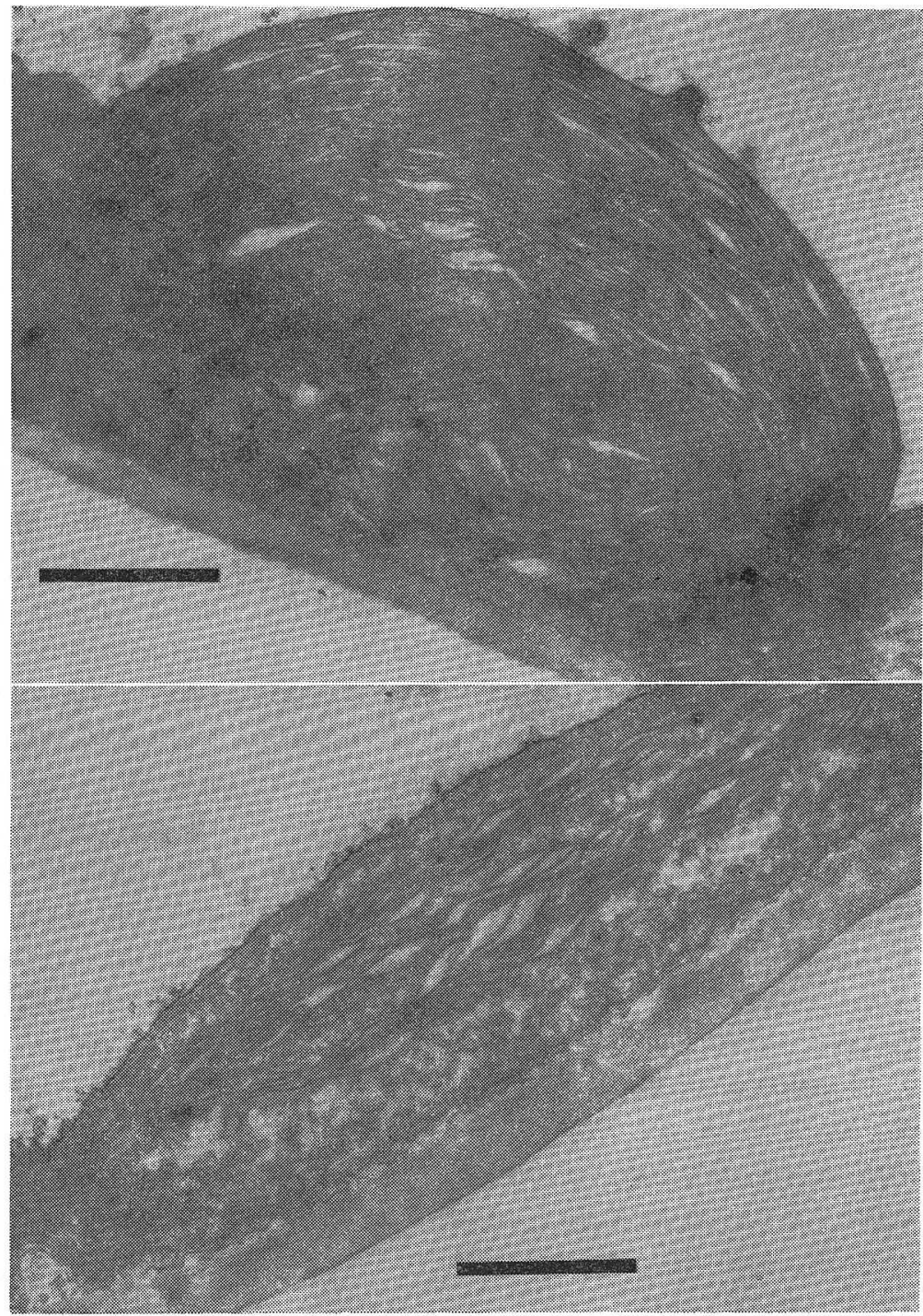

暗中（A）および光照射下（B）で，オスミウム酸で固定された ホウレンソウ緑葉中の葉緑体の電子顕微鏡像 (-1

なおある種の条件下，とくにリン酸イオンが存在せ ずにフェナジンメトサルフェートが存在するよらな条 件下では，光により葉緑体が著しく膨潤することが知 られている(西田ら, Packer ら). 光収縮の機作は, これら関連諸現象の研究から解明されていくよらに思 われる。

以上，葉緑体の光収縮現象，打よびそれにまつわる 最近の光合成研究の動向を略記してみた.上記のほか, 悲濁液の $\mathrm{pH}$ 饻化，和よび暗中で Hill oxidant によ り酸化した葉緑体を化学的に還元する操作などにより,
葉緑体からクロロフィルの管光に類似した発光が見ら れるという報告があるが (Claytonら)，これらの発見 なども，光合成現象といら牙城にせまるうえの重要な 大テップになろら，葉緑体が光収縮または $\mathrm{pH}$ にる 構造変化をする際には，葉緑体の構成体，たとえばラ メラおよび葉緑体膜などの構造が変化するわけである が，その実態は現在な挌さだかでない、構造変化の実 態がとくに化学の言葉で表現されるようになれば，光 合成の研究はさらに大きく進展しよう，この方向の研 究が強く望まれる次第である.

(東京工業大学理学部化学科生物化学教室) 